\title{
KÖRNYEZET ÉS PÉNZÜGYEK: A PÉNZÜGYI FEJLETTSÉG EMISSZIÓT BEFOLYÁSOLÓ SZEREPE' ${ }^{1}$
}

\author{
Németh-Durkó Emilia²
}

A károsanyag-kibocsátás és a gazdasági növekedés összefüggő folyamatok, kapcsolatuk vizsgálatában a pénzügyi fejlettség gazdaságélénkítő szerepe miatt egyre nagyobb figyelmet kap. A fejlett pénzügyi rendszerű gazdaságokban a hitelezési lehetőségek bővülése és az aktív tőzsdei jelenlét hozzájárul a beruházások, fejlesztések finanszírozási nehézségeinek csökkentéséhez egyéni és vállalati szinten is. A finanszírozásban a tőzsdei portfóliók is szerepet kapnak, melyek között népszerủek a fenntarthatósági célok megvalósulását elősegítő zöldbefektetések. Olyan korszerü beruházások valósulhatnak meg, amelyekkel energiamegtakarítás érhető el, és kevesebb károsanyag-kibocsátással járnak. Kutatásunkból kiderül azonban, hogy a pénzügyi fejlettség hatása nem egyértelműen kedvező, nemcsak a környezetbarát technológiák terjedésének lehet a mozgatórugója, hanem a hatékonyságbeli javulás ellenére összességében az energiafogyasztást és a károsanyagkibocsátást is fokozhatja.

JEL-kódok: G10, Q48, Q56

Kulcsszavak: pénzügyi fejlettség, gazdasági növekedés, károsanyag-kibocsátás, zöldpénzügyek

\section{BEVEZETÉS}

Az egyre növekvő légköri szennyezettség korunk egyik legnagyobb problémája, amely országokon átívelő kihívást jelent fejlett és fejlődő országoknak egyaránt. A globális felmelegedés és okainak kutatása, következményeinek enyhítése világszerte vonzza a kutatók figyelmét. A környezet állapotának romlásában és az átlaghőmérséklet emelkedésében nagy szerepet tulajdonítanak a levegőbe kerülő

1 A tanulmány alapjául szolgáló kutatást az Innovációs és Technológiai Minisztériuma által meghirdetett Tématerületi Kiválósági Program 2020 - Intézményi Kiválóság Alprogram támogatta a Budapesti Corvinus Egyetem 'Pénzügyi és Lakossági Szolgáltatások' tématerületi programja (TKP2O2O-IKA-02) keretében.

2 Németh-Durkó Emilia tanársegéd, Befektetések és Vállalati Pénzügy Tanszék, Budapesti Corvinus Egyetem. E-mail: durko.emilia@uni-corvinus.hu. 
üvegházhatású gázok egyre nagyobb mennyiségének, föként a légkörbe jutó széndioxid-kibocsátás tartalmának. A levegő szennyezettsége több európai városban rendszeresen átlépi azt a határétéket, amely már az emberi szervezet egészségére is káros hatással van.

A klímaváltozás költségei dollármilliárdokra rúgnak, de a nem cselekvés ára még a legdrágább forgatókönyvnél is magasabb. A 2015-ös párizsi klímacsúcson az aláírók vállalták, hogy törekednek az átlaghőmérséklet-emelkedés 2 Celsius fok alatti visszafogására, hiszen már félfokos emelkedés is visszafordíthatatlan károkat okoz az embernek és a környezetnek is. Ha ez sikerül, a kutatók számításai szerint a következő 50 évben a klímaváltozás megelőzésének és kockázatának mérsékléséből adódó költségei még így is megközelítik a 2 ezer milliárd dollárt, amelyből például városokat kell a természeti katasztrófák után újjáépíteni. A nem cselekvés ára, azaz szigorítások nélkül a jelenlegi helyzet fenntartása azonban háromszor ekkora költséggel fog járni (IPCC, 2014). A környezeti károk finanszírozása kihívás elé állítja a pénzügyi szektort is.

A fent említett okokból sokan kutatták a szén-dioxid-kibocsátásra ható tényezőket, szignifikáns válaszokat keresve a károsanyag-kibocsátás megmagyarázására például a jövedelem emelkedésével, a népesség növekedésével, az urbanizációval, a határokon átívelő kereskedelmi kapcsolatok sokaságával vagy éppen az energiafogyasztással. Az elmúlt években olvashattunk arról is, hogy a pénzügyi fejlettség is egy lehet az emissziót befolyásoló tényezők közül.

A pénzügyi fejlettségi szint emelkedése jó indikátora lehet annak, hogy a gazdaságok képessé váljanak egy alacsony karbonintenzitású gazdaságra történő átállásra, amely a Párizsi Megállapodás 2050-re kitűzött céljai között szerepel. A fejlett pénzügyi rendszerü országok a könnyebb és átláthatóbb hitelezési folyamatokkal és alacsony kamatokkal fellendíthetik a környezettudatos technológiák elterjedését. A fejlett gazdaságokban általában aktívabb a tőzsde, ami egyre nagyobb teret ad a portfóliókban a környezettudatos befektetési célok finanszírozásának, a tőzsdei cégek pedig reputációs célokból is erősíthetik környezeti elköteleződésüket. Ezért a tőzsdei aktivitásnak is lehet pozitív hozadéka a környezetre nézve. A tanulmány célja, hogy elemezze a pénzügyi szektor fejlettségének szerepét a környezetvédelemben, azaz a károsanyag-kibocsátás csökkentésében, és magyarázattal szolgáljon a szakirodalom ellentétes empirikus eredményeire. A második fejezetben a pénzügyi rendszereket és a pénzügyi fejlettség gazdasági szerepét ismertetjük, kitérünk a pénzügyi fejlettség mutatóira is. A harmadik fejezetben pedig a természeti környezet állapotával hozzuk összefüggésbe, és bemutatjuk a pénzügyi fejlettség kétpólusú hatásának magyarázatát, néhány empirikus példát ismertetve. A negyedik fejezetben összegző gondolataink olvashatók. 


\section{A PÉNZÜGYI RENDSZEREK A GAZDASÁGBAN}

A pénzügyi szektor fejlettsége a pénzügyi rendszerek teljes folyamatában megjelenik. A fejezet a pénzügyi rendszerek elemeinek gyors áttekintése után a pénzügyi fejlettséget meghatározó tényezőket mutatja be, és ismerteti a szakirodalomban alkalmazott mérőszámait.

\subsection{A pénzügyi fejlettség gazdasági szerepe}

A pénzügyi rendszerek olyan alapvető funkciókat látnak el, amelyek biztosítják a gazdasági erőforrások időbeli, határokon átnyúló és iparági átcsoportosítási módjait, és kezelik az ezzel együtt járó kockázatokat (Merton-Bodie, 1995). Niemeyer (2001) úgy véli, hogy a pénzügyi piacok teszik lehetővé a vállalatok és az egyéni szereplők számára, hogy hatékonyan kezeljék a gazdasági bizonytalanságokat és megosszák a kockázatokat.

A pénzügyi rendszerek feladata komplex a gazdaság szereplőinek kiszolgálásában, öt funkcióját különböztetjük meg (World Bank, 2012):

a) előzetes információk előállítása a lehetséges befektetésekről;

b) a befektetések nyomon követése a finanszírozás biztosítása után;

c) a kereskedés, a diverzifikáció és a kockázatkezelés megkönnyítése;

d) a megtakarítások mobilizálása;

e) az áruk és szolgáltatások cseréjének megkönnyítése.

Összefoglalva úgy lehetne jellemezni, hogy a pénzügyi piacok és intézmények fö szerepe a tőkeallokáció hatékonyságának javítását és a megtakarítások kezelését jelenti egy gazdaságban.

A pénzügyi szektor fejlesztése tehát ebben az ötkomponensü rendszerben felmerülő, hatékonyságjavulásra irányuló, költségcsökkentő szerepben érvényesül. „Az információs és tranzakciós költségek csökkentéséhez a pénzügyi közvetítőrendszer a megtakarítások mobilizálásán, a kockázatok diverzifikálásán, a megtakarítások új befektetések felé való irányításán, illetve a megfinanszírozott projektek megfigyelésén keresztül tud hozzájárulni” (Mérő, 2003:591).

A pénzügyi szektor fejlődéséről akkor beszélhetünk, amikor a pénzügyi eszközök, a piacok és a közvetítők enyhítik az információs, végrehajtási és tranzakciós költségek hatásait, és javítják a pénzügyi szektor kulcsfontosságú funkcióinak ellátásában a gazdaságot (World Bank, 2012). A gazdaság számára előnyös a fejlett pénzügyi rendszer, hiszen egy jól fejlett pénzügyi piacon a gazdaság megtakarítását nyereséges befektetésekbe csatornázzák (Stiglitz-Weiss, 1983; Diamond, 1984). Azok az országok, amelyeknek ma fejlettebb pénzügyi rendszerük van, várható- 
an gyorsabban fognak növekedni a következő évtizedekben (Levine, 2001; Mérő, 2003).

A pénzügyi fejlettséget az intézményrendszerek és a tőkepiacok jellemzőiből határozzuk meg (1. ábra). A hozzáférés, a mélység és a hatékonyság mind-mind olyan mérhető paraméterei, amelyek a pénzügyi szolgáltatásokhoz való hozzáférésről, a szerződések megbízhatóságáról és minőségéről nyújtanak információt. Az IMF (2020) kiegészíti a felsoroltakat a stabilitás dimenziójával is.

\section{1. ábra}

\section{A pénzügyi fejlettséget meghatározó tényezők}

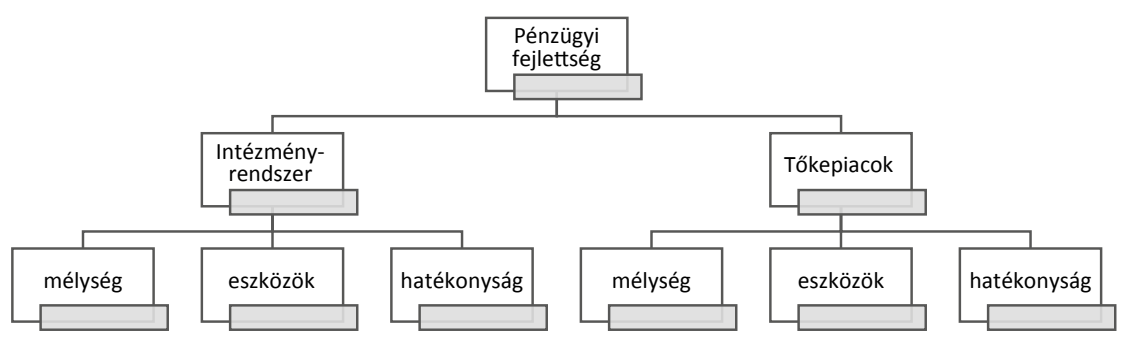

Forrás: saját szerkesztés IMF (2019) alapján

Empirikus kutatások szerint egy jól működő pénzügyi rendszer az információs és tranzakciós költségek enyhítésével fellendítheti a gazdasági növekedést, és egyúttal csökkentheti a szegénységet (Levine, 1991; Bencivenga et al., 1995). Erőteljes, pozitív kapcsolatot találtak (Beck-Levine, 2003) a pénzügyi közvetítői fejlettség és az egy före jutó gazdasági növekedés, valamint a teljes tényező termelékenységének növekedése között, amelyből szintén a pénzügyi fejlettség gazdaságélénkítő szerepe igazolható.

Számos tanulmány bizonyítja, hogy a gazdasági növekedés és a nemzeti jövedelem a pénzügyi fejlettséggel biztosan korrelál, legyen szó akár egy magasabb jövedelmű, fejlett vagy egy alacsonyabb jövedelmű, fejlődő országról (Guiso et al., 2005; Christopoulos-Tsionas, 2004; Calderòn-Liu, 2003). A bankszektor fejlődése és a pénzügyi fejlettség növekedése hozzájárul a gazdasági növekedéshez (Giovanni et al., 2013), ezért úgy vélem, kiemelten fontos szerepe van egy gazdaságban annak is, hogyan alakul ez a mutató.

A pénzügyi fejlettség nemcsak a gazdasági növekedés előmozdítását szolgálja, hanem ezáltal a jövedelem egyenletesebb elosztását is. Stiglitz (2012) egyik megállapítása, hogy a magas egyenlőtlenség visszaveti a gazdasági hatékonyságot és a termelékenységet. Baiardi-Morana (2016) szerint a jövedelem egyenletesebb 
elosztása érdekében támogatandó a pénzügyi rendszerek fejlettsége, de mindenképpen annak a figyelemmel kísérése.

Mint láthattuk, a pénzügyi fejlettség alakulása egy gazdaságban fontos információkat szolgáltat, hozzájárulhat a gazdasági növekedéshez és az egyenlőtlenségek csökkentéséhez is. A pénzügyi fejlettség mérése nehéz - például a gazdasági növekedéssel ellentétben, korántsem egyetlen mutatónak a függvénye. A következő fejezetben részletesen bemutatom, milyen mutatókkal mérhetjük a pénzügyi fejlettséget.

\subsection{A pénzügyi fejlettség lehetséges mérőszámai}

A pénzügyi fejlettség mérése elengedhetetlen a pénzügyi szektor fejlődésének nyomon követéséhez és a gazdasági növekedésre gyakorolt hatását megértéséhez. A gyakorlatban azonban nehéz mérni a pénzügyi fejlettséget, mivel, mint az 1 . ábrán bemutattuk, több dimenzióval rendelkezik.

A pénzügyi fejlettségre nincsen egységes definíció, és mérésére kizárólagos mutatószám sincs a szakirodalomban. A szerzők elgondolása a megfelelő mutatóról még csak abban sem egyezik, hogy egy kiválasztott indikátorral számoljanak, vagy több mutatóval fedjék le a pénzügyi szektor fejlettségének jellemzőit. Kétfelé ágazik a módszertan: vagy egyszerüen a modellben látunk több mutatót, vagy a több mutatóból egy készül, például fökomponens-elemzéssel (Hayat et al., 2018; Coban-Topcu, 2013). Az 1. táblázat foglalja össze a pénzügyi fejlettség mérésének megoldásait.

\section{1. táblázat}

A pénzügyi fejlettség mutatói

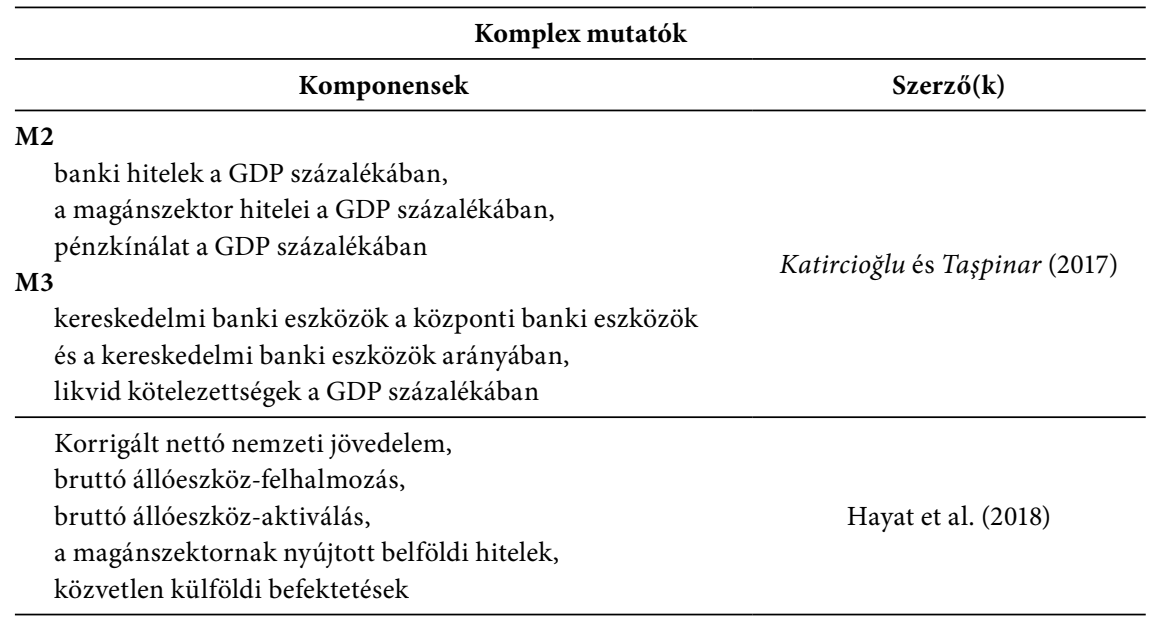




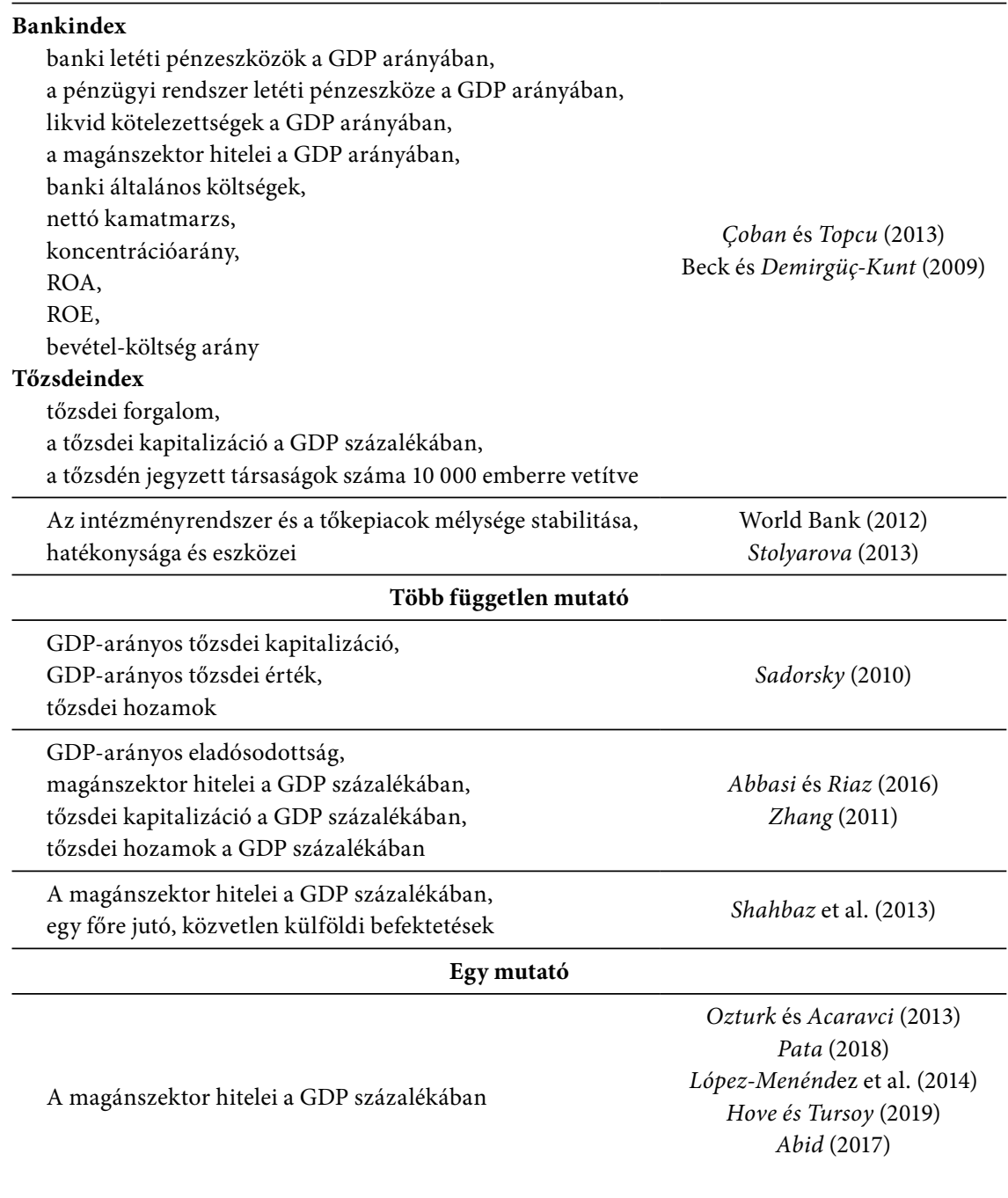

Forrás: saját adatgyüjtés

Katircioğlu és Taşpinar (2017) saját indexet készített, amely részben mutatott szignifikáns eredményeket az öt különböző mutatóból készített indikátorral. Hayat et al. (2018) főkomponens-elemzéssel dolgozott, így a korrigált nettó nemzeti jövedelem, a bruttó állóeszköz-felhalmozás, a bruttó állóeszköz-aktiválás, a belföldi hitel a magánszektorban, közvetlen külföldi befektetések képezték mutatójának alapját. Az így kapott pénzügyi mutató szignifikáns összefüggést mutatott az energiafelhasználással. A gazdasági növekedés helyett pedig gazdasági fejlettséget használt, amelyet szintén több mutatóból épített indexszel modellezett. Coban- 
Topcu (2013) szintén a főkomponens-elemzést alkalmazta a multikollinearitás elkerülése miatt (2013), két mutatót képezett négy indexből. Beck és DemirgüçKunt (2009) tanulmánya alapján alakították ki a bankindexet és a tőzsdeindexet, némi korrekcióval az adatok korlátotott elérhetősége miatt.

A tőzsde szerepe is előkerül, noha kevesebb tanulmányban. Sadorsky (2010) úttörőként a tőzsdei szerep mérésére három külön mutatót használ: a GDP-arányos tőzsdei kapitalizációval, a GDP-arányos kereskedett tőzsdei értékkel és a tőzsdei hozamokkal dolgozik. Ez a megoldás többnyire nem mutatott szignifikáns eredményeket. Mások (Coban-Topcu, 2013; Abbasi-Riaz, 2016) megcáfolták ezt az eredményt, és úgy vélik, a tőzsdék jelentős hatással vannak a gazdasági tevékenységekre, az energiafogyasztásra és a szén-dioxid-kibocsátásra is.

Az empirikus munkák a pénzügyi fejlettség mérésére a hitelek GDP-hez viszonyított nagyságát használták, amellyel a lakosság vásárlási hajlandóságát is mérik (Octurk-Acaravci, 2013; Pata, 2018, Hove-Tursoy, 2019; Abid, 2017). Egy ország pénzügyi szektora azonban különféle pénzügyi intézményeket, piacokat és eszközöket tartalmaz, míg ezek a mutatók csak egy-egy szegmensét ragadják meg. Alkalmazásuk mellett szól kétségtelenül a mutatók könnyü hozzáférhetősége, amely a világ legtöbb gazdaságáról szolgáltat kellő hosszúságú idősoros adatot az elemzésekhez, azonban ezen mutatók csak durva becslést adhatnak a pénzügyi fejlettségről, mert nem tartalmazzák annak minden aspektusát.

A World Bank (2012) globális pénzügyi fejlesztési adatbázisa egy átfogó, mégis viszonylag egyszerü keretet fejlesztett ki a pénzügyi fejlettség mérésére. Ez a keretrendszer a jól működő pénzügyi rendszert jellemző tényezők négy csoportját azonosítja: a pénzügyi mélység, a hozzáférés, a hatékonyság és stabilitás. Ezt a négy dimenziót mérik a pénzügyi szektor két fö elemére, a pénzügyi intézményekre és a pénzügyi piacokra (World Bank, 2012; IMF, 2020). Már a szakirodalomban is találkozunk olyan munkákkal, amelyek ezzel a mutatóval dolgoznak (NémethDurkó, 2020; Stolyarova, 2013). 


\section{A PÉNZÜGYI FEJLETTSÉG SZEREPE A TERMÉSZETI KÖRNYEZET ÁLLAPOTÁBAN}

A pénzügyi fejlettség szerepe kettős a károsanyag-kibocsátásra nézve. A fejezet ismerteti a két ellentétes nézőpont mögöttes okait, majd empirikus eredményeket mutat be.

\subsection{Hatások és ellenhatások}

A pénzügyi fejlettség a pénzintézetek tőkeáramlása, a tőkepiacok és a közvetlen külföldi befektetések mértékével függ össze, és ezen három mechanizmuson keresztül befolyásolja is a környezeti minőséget (Zhang, 2011). A fejlődő gazdaságok gyakran kompromisszumra kényszerülnek a gazdasági növekedés és a környezetromlás között, és néhány fejlettebb gazdaság kiaknázza a legkevésbé fejlett országok gyenge környezetvédelmi politikáját (Horvath et al., 2018). Jelenleg két álláspont van a pénzügyi fejlődés energiafogyasztásra és károsanyag-kibocsátásra gyakorolt hatásáról. Az egyik nézet szerint támogatja a háztartások és a vállalkozások növekvő hitelezését további vásárlások ösztönzésére (gépek, berendezések), ezáltal növelve az energiafogyasztást. A növekvő energiafogyasztás pedig növelheti a szén-dioxid-kibocsátást (Chang, 2015), ily módon károsítva a környezetet. A másik nézet szerint az új termékek egyúttal szükségszerüen környezetbarát és energiatakarékos eszközök is, és ezek beszerzését segítik a könnyen hozzáférhető hitelek. Az új, modernebb eszközök végső soron kevesebb emissziót termelnek, ezért a régi eszközök cseréje csökkenti az energiafelhasználást, és (nem feltétlen lineárisan) a károsanyag-kibocsátást is.

A pénzügyi fejlettségnek a szén-dioxid-kibocsátásra gyakorolt hatásáról a két fenti álláspontnak megfelelően ellentétes eredményeket találunk a szakirodalomban is. Mindkét nézet megegyezik abban, hogy a hatás közvetett, és a gazdasági növekedéssel összefügg. A környezeti hatásának értelmezését a vállalati hiteleken, a projekthiteleken és a tőzsdei jelenléten keresztül mutatom be (2. ábra), amelyek meglepő módon csökkenthetik és növelhetik is az emissziót. 


\section{2. ábra}

A pénzügyi fejlettség csatornái a károsanyag-kibocsátás befolyásolására

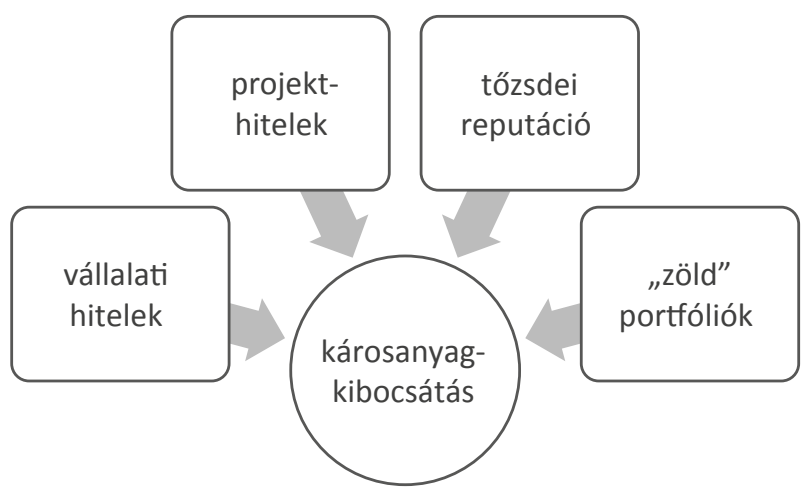

Forrás: saját szerkesztés

Egyes kutatók (Shahzbaz et al., 2013; Claessens-Feijen, 2007; Halicioglu, 2009; Tamazian-Rao, 2010) szerint a pénzügyi fejlődés a szén-dioxid-kibocsátás csökkentéséhez járul hozzá, amely a hitelekkel magyarázható, mert a környezetkímélő szerep pozitív hozadéka a vállalati hiteleknek. A termelés hatékonyságának javítása, a költségek csökkentése és a versenyképesség javítása motiválja a vállalati szereplőket, a felújítások és a gépparkok modernizációjának finanszírozási hátterét pedig jórészt hitelből biztosítják. Claessens-Feijen (2007), Halicioglu (2009) és Tamazian-Rao (2010) szerint egy fejlett pénzügyi rendszerü gazdaság zöld, környezetbarát projektekkel mikro- és makroszinten is támogathatja a beruházásokat, fejlesztéseket, hozzájárulva az energiaköltségek (és az energia mennyiségének) csökkentéséhez is, közvetett módon pedig az emisszió mérsékléséhez.

A bankok hitelezése nemcsak a mikroszereplőket, hanem a kormányokat is segítheti a környezet degradációjának visszaszorításában. A tiszta energiát vagy más környezettudatos megoldást népszerüsítő zöldprojektek megvalósulához elengedhetetlen a bankok szerepe. A megfelelő szakpolitikai megállapodás alapján a pénzügyi intézmények biztosíthatnák a szükséges forrásokat e projektek vagy programok müködtetéséhez, amelyek hozzájárulnak az energetikai infrastruktúra javításához és végül a szén-dioxid-kibocsátás csökkentéséhez (Jiang-Ma, 2019).

A károsanyag-kibocsátás csökkentésének egyik, de nem kizárólagos módja a hatékonyság javítása. Emissziócsökkentés új, alternatív energiatermelö rendszerekre történő átállással is elérhető. A megújulóenergia-ágazatnak nyújtott hitelezés fontos eleme lehet egy fejlett pénzügyi rendszerủ gazdaságnak, amely a zöldenergia-projektek elterjedéséhez is hozzájárulhat akár hitelezéssel, akár tőkefinan- 
szírozással (Dasgupta et al., 2004). Továbbá olyan technológiai innovációkat is támogat, amelyek tovább csökkenthetik az energiafelhasználást (Beck et al., 200o; Alfaro et al., 2006), illetve a fosszilis üzemanyagokról tiszta energiára való áttérést (Berlinger-Lovas, 2015).

A tőzsdei jelenlét mérése is megjelenik a szakirodalomban mint a pénzügyi fejlettség komplex mutatójának egyik alkotóeleme. A tőzsdén jegyzett cégek szerepe nemcsak a részvények kereskedéséhez köthetö, hanem a reputációjukhoz is. A tőzsdei cégek a reputációjuk javítása miatt különös hangsúlyt fektetnek a társadalmi és a környezeti értékek képviselésére (Lanoie et al., 1997; Paramati et al., 2016), amelynek gyakorlati megvalósulása lehet például, hogy a termelésben és müködésben is alkalmaznak környezetbarát technológiákat, amellyel csökkenthetik a szén-dioxid-kibocsátást.

A környezeti (Environmental), társadalmi (Social) és kormányzati (Governance) faktorok, azaz az ESG-szempontok szerepe egyre erősödik a pénzügyi világban és a pénzügyi döntéshozatalban (Naffa-Dudás, 2020). „A nemzetközi zöldpénzügyi (green finance) szegmens negyedévről negyedévre rekordokat dönt, és már nemcsak kis, etikus mellékszereplők foglalkoznak vele, hanem a fejlett pénzügyi piacokon egyre inkább a fö iránnyá válik. A világ vezetői bankjai között ma már nem igazán találunk olyat, amely ne rendelkezne kifejezetten zöldhitel-portfólióval, társadalmilag felelös (ESG-alapú) vagyonkezeléssel vagy éppen általa kibocsátott zöldkötvénnyel" (Gyura, 2019).

A kutatók másik csoportja a pénzügyi fejlettség hatását környezetszennyezőnek titulálja, és a gazdasági növekedést figyelembe véve is csak kedvezőtlenebb tendenciákat vetít előre. A hitelezésben olyan ösztönzőt látnak, amely egyértelműen a szén-dioxid-kibocsátás fokozásához vezet. Egy jól működő pénzügyi rendszer képes hatékonyan megszüntetni az információs aszimmetria problémáját, és kibővítheti a finanszírozási csatornákat. A vállalkozások számára ez azt jelenti, hogy jóval alacsonyabb költségek mellett juthatnak beruházási hitelhez. A hitelek könnyü elérhetősége motiválja a termelési skála bővülését, több eszköz vásárlását, ezért jelentősen növeli a szén-dioxid-kibocsátást, de legalább az energiafogyasztást (Ozturk-Acaravci, 2013). A pénzügyi szektor fejlödése jobb és hatékonyabb szolgáltatást nyújt a háztartások fogyasztási hiteleihez, megkönnyítve a háztartások időben eltolódó fogyasztásának elörehozását, és további áruk, például ingatlanok, gépjárművek és egyéb elektromos készülékek vásárlására ösztönzi őket. Hosszú távon a társadalmi fogyasztás bővülését vetíti elő (Jiang-Ma, 2019).

A tőzsde szerepe ebben a megközelítésben a gazdasági növekedéssel magyarázza a környezetszennyező hatást. A tőzsde a gazdasági viszonyok fontos barométereként működik, a tőzsde jó teljesítménye a gazdaság gyors növekedését és az általános társadalmi jólét növekedését vonja maga után (Fain-Naffa, 2019; Jiang-Ma, 2019). A jólét nagymértékben növeli a vállalkozások és a fogyasztók fo- 
gyasztását, az energiafogyasztás és a szén-dioxid-kibocsátás növekedéséhez vezet üzleti tevékenységük fokozásával (Sadorsky, 2010, 2011; Mankiw-Scarth, 2008). A hatékonyságjavulás nem vitatott, de oly mértékben bővülnek a beszerzések, hogy a visszapattanó hatás érvényesül: a környezetbarát technológiák hasznát (emissziómegtakarítását) felülmúlja az eszközök együttes többletemissziója.

Összességében két hatás érvényesülését igazolják a szakirodalmak: a pénzügyi fejlettség ösztönözheti a megnövekedett energiaigény helyettesítését (csökkentve az energiafogyasztást és a károsanyag-kibocsátást), ugyanakkor biztosítja az energiaipar hitelezési tőkéjét (növelve az energiafogyasztást és a károsanyag-kibocsátást). A tőzsde a portfólióban megjelenő vállalatok környezettudatos magatartását kétféle módon erősítheti: egyrészt saját müködésük és fogyasztásuk átalakításával, másrészt a tőzsdén kereskedett ESG-alapok vagy zöldportfóliók terjedésével járulhat hozzá a károsanyag-kibocsátás csökkentéséhez.

\subsection{Néhány empirikus eredmény}

Az első tanulmányokban - Claessens-Feijen (2007), Halicioglu (2009) és Tamazian-Rao (2010) - úgy vélik, hogy a pénzügyi szektor fejlődése valószínűleg kiváló pénzügyi szolgáltatásokat biztosít a környezetbarát programok számára, mindezt olcsó finanszírozási költségek mellett, és így hozzájárul a károsanyag-kibocsátás csökkentéséhez. Később igen népszerű módszer lett a pénzügyi szektor valamilyen formában történő beépítése az elemzésekbe.

Egy évtizeddel ezelőtt még nagyon keveset tudtunk a pénzügyi mutatók energiafogyasztásra, környezetre gyakorolt hatásairól (Sadorsky, 2010). A témába vágó cikkek egyharmadát közlö vezető lapokban (Journal of Cleaner Production, Renewable and Sustainable Energy Reviews, Energy Policy) csak néhány publikációt olvashattunk, amely a pénzügyi fejlettség környezetminőségben betöltött funkcióját tárgyalja. A pénzügyi lapok pedig csak jóval később, 2015-től kezdtek el érdeklődni az energia-károsanyag-kibocsátás-gazdasági növekedés területe iránt.

Katircioğlu-Taşpinar (2017) a pénzügyi fejlettséget a gazdasági növekedés energiafogyasztást mérséklő tényezőjeként építették modelljükbe. Eredményük, hogy rövid távon egy fejlettebb pénzügyi rendszer elösegíti a sikeres energiagazdálkodást és a környezetvédelmi célok teljesülését a károsanyag-kibocsátás csökkentésével. Hosszú távon azonban pozitív összefüggést tapasztaltak, ezért szerintük különösen fontos a hosszú távú tervezés, és a környezetvédelmi és gazdasági célok összehangolása, hiszen ezen eredményük szerint ebben még ellentmondás van. Sadorsky (2010) nem ért egyet, számításaiból arra következtethetünk, hogy a pénzügyi fejlettség nem üdvözlendő folyamat a klímaváltozás elleni harcban. 
A 22 országot tartalmazó paneladatbázis eredménye, hogy a pénzügyi szektor finanszírozási képességének javulása növeli az energiafogyasztást.

Ozturk és Acaravci munkái a legtöbbet hivatkozott tanulmányok között szerepelnek. A 2013-as cikkükben közel 60 éves periódust vizsgáltak, és azt találták, hogy oksági a kapcsolat a pénzügyi fejlettség változója és az energiafogyasztás, illetve szén-dioxid-kibocsátás között. Rövid távon az ok-okozati kapcsolat a pénzügyi fejlődéstől indul az egy före jutó energiafogyasztás felé. A pénzügyi szektor terjedése magasabb jövedelmeket és növekvő energiafogyasztást eredményez (Ozturk-Acaravci, 2013), megerősítve Sadorsky (2010) álláspontját.

Pata (2018) az 1974-2014 közötti időszakra figyelte meg a szóban forgó változók kölcsönhatásait, kiegészítve az urbanizációval. Az urbanizáció fontosságát azzal indokolta, hogy a legtöbb város gyorsabban fejlődik, nagyobb mértékben járul hozzá a nemzeti jövedelemhez, mint az országos átlag. Ezért, ha az ilyen jellegü területek indulnak növekedésnek, a lakosság urbanizáltabbá válásával nagy nyomást gyakorol a városi erőforrásokra és a környezetre, végső soron fokozott szennyezéshez vezet $(\mathrm{Li}-\mathrm{Yao}, 2009)$. Három kointegrációs vektor mellett Pata (2018) megállapította, hogy a gazdasági növekedés, pénzügyi fejlettség és az urbanizáció egyaránt környezeti degradációt fokozó folyamatok. Nagy meglepetésükre, az alternatív energiák felhasználásának nincs hatása. A legfontosabb tényező a szén-dioxid-kibocsátás alakulásában a gazdasági növekedés, amit az urbanizáció, majd a pénzügyi fejlettség követ.

Összességében változatos eredményekkel találkozunk, és egy még részletesebb irodalmi beszámoló is ezt támasztaná alá. Az eltérő hatásokban egy ország jövedelmi helyzetének nagy befolyásoló szerepe van (Mazur et al., 2015; Pablo-Romero és Sánchez-Braza, 2017), ezért egy sokk a jövedelemben másként hathat egy fejlettebb, mint egy fejlődő gazdaságra, és míg egyik esetében fokozza, a másik országnál ugyanaz a sokk csökkentheti a károsanyag-kibocsátást.

\section{4. ÖSSZEFOGLALÁS}

Jelen tanulmányban azt vizsgáltuk, összefüggésbe hozható-e a pénzügyi fejlettség a természeti környezet állapotának megőrzésével. A környezeti állapotot a károsanyag-kibocsátás nagyságával, legtöbbször a szén-dioxid-kibocsátás alakulásával mérik, ezért mi is e mutatóval kerestük a pénzügyi világhoz való kapcsolódását. A hatás erős, ám közvetett jellegét igazolták a szakirodalmak, miután a pénzügyi fejlettségnek jelentős gazdaságélénkítő szerepe van, képes a gazdasági növekedés fokozására. Ezért érdemes úgy vizsgálni ezt a területet és olyan modelleket alkotni, hogy a nemzeti jövedelmet és annak környezeti hatását is figyelembe vegyük a pénzügyi hatások értékelésekor. 
A pénzügyi fejlettség mérése komplex, legtöbbször több dimenziós indikátorral történik, amely egyaránt méri a pénzügyi intézményi hátteret és a tőkepiacok működését is: az eszközökre, a mélységre, a hatékonyságra és a stabilitásra fókuszálva alkot egy mutatót. Az empirikus irodalmak a könnyü hozzáférhetősége miatt gyakran csak a magánszektor GDP-arányos hitelnagyságát alkalmazzák a pénzügyi fejlettség méréséhez, azonban ez csupán egy szegmense a pénzügyi rendszereknek. A teljes hatás megismeréséhez javasolt a tőzsdei jelenlét erősségét is mérni, amely a tőzsdén kereskedett zöldportfóliók volumenének növekedésével és a tőzsdei cégek reputációs céljának teljesülésével gyakorolhat hatást a károsanyag-kibocsátásra.

Az irodalomkutatásból kiderült, hogy egyrészt a fejlett pénzügyi rendszer az elérhetőség javításával és a tranzakciós költségek csökkentésével a hitelezési folyamaton keresztül a vállalati és az egyéni szereplők fogyasztására gyakorolt hatással hozható összefüggésbe a környezeti állapottal. Másrészt ki kell egészíteni a mérést egy gazdaság tőzsdei jelenlétének a hatásával. A környezet és pénzügyek kapcsolatánál két ellentétes álláspontot ismertünk meg. A finanszírozási akadályok felszámolásával olyan korszerü és energiatakarékos gépek, berendezések beszerzésére nyílik lehetőség, amelyek a lecserélt régiekhez képest kevesebb energiát fogyasztanak, és kevesebb károsanyag-kibocsátást is generálnak. A másik nézőpont eltérően gondolkozik: hiszen ha túlságosan felélénkül a gazdaság és a hitelezés, akkor a fogyasztás növekedése és az elörehozott fogyasztások összességében, a fajlagos energiahatékonyság javulásának ellenére, többletenergia-fogyasztást okoznak, amely a károsanyag-kibocsátást fokozza.

A környezet és pénzügyek két olyan terület, amely egyre inkább összefonódik a modern gazdaságokban. A kapcsolat iránya gazdaságspecifikus jellemzőkön múlik, ezért szakirodalom-feldolgozásunk eredményei alapján úgy gondoljuk, általános következtetések helyett egy-egy konkrét gazdaságra lenne érdemes értékelni a két változó, a pénzügyi fejlettség és a károsanyag-kibocsátás kapcsolatát.

\section{HIVATKOZÁSOK}

Abid, Mehdi (2017): Does economic, financial and institutional developments matter for environmental quality? A comparative analysis of EU and MEA countries. Journal of Environmental Management 188, 183-194. DOI: 10.1016/j.jenvman.2016.12.007.

Aвbasi, Faiza - Riaz, Khalid (2016): $\mathrm{CO}_{2}$ emissions and financial development in an emerging economy: An augmented VAR approach. Energy Policy 90, 102-114. DOI:10.1016/j. enpol.2015.12.017.

Alfaro, L. - Chanda, A. - Kalemli, O. - Sayek, S. (2006): How does foreign direct investment promote economic growth: Exploring the effects of financial markets on linkages? No. 07-013, Harvard Business School, https://www.nber.org/papers/w12522. 
Baiardi, Donatella - Morana, Claudio (2016): The financial Kuznets curve: Evidence for the euro area. Journal of Empirical Finance 39, 265-269. DOI:10.1016/j.jempfin.2016.08.003.

Beck, Thorsten - Levine, Ross - Norman, Loayza (2000): Financial intermediation and growth: causality and causes. Journal of Monetary Economics 46, 31-77.

Beck, Thorsten - Ross, Levine (2003): Stock Markets, Banks and Growth: Panel Evidence. Journal of Banking and Finance 28(3), 423-442.

Beck, Thorsten - Demirgüç-Kunt, Asli - Levine, Ross (2004): Finance, inequality, and poverty: crosscountry evidence. National Bureau of Economic Research. https://www.nber.org/papers/ w10979.

Bencivenga, Valerie - Smith, Bruce - Starr, Ross M. (1995):Transactions Costs, Technological Choice, and Endogenous Growth. Journal of Economic Theory 67, 53-177. DOI: doi.org/10.1006/ jeth.1995.1069.

Berlinger, Edina-Lovas, Anita (2015): Fenntarthatóság és növekedés. A Stern-jelentés és az irányított technológiaváltás modellje. Külgazdaság, 59(7-8), 65-81.

Calderon Caesar - Liu, Lin (2003): The Direction of Causality between Financial Development and Economic Growth. Journal of Development Economics 72(1), 321-334.

Chang, Shu-Chen (2015): Effects of financial developments and income on energy consumption. International Review of Economics and Finance 35, 28-44. DOI: 10.1016/j.iref.2014.08.011.

Christopoulos, Dimitris - Tsionas, Mike (2004): Financial Development and Economic Growth: Evidence from Panel Unit Root and Cointegration Tests. Journal of Development Economics 73(1), 55-74. DOI: doi.org/10.1016/j.jdeveco.2003.03.002.

Claessens, Stijn - Feijen, Erik (2007): Financial sector development and the millennium development goals. January 2006. World Bank Working Paper.

Coban, Serap - Topcu, Mert (2013): The nexus between financial development and energy consumption in the EU: A dynamic panel data analysis. Energy Economics 39, 81-88. DOI: 10.1016/j.eneco.2013.04.001.

Dasgupta, Susmita - Hong, Jong H. - Laplante, Benoit - Mamini, Nlandu (2004): Disclosure of environmental violations and stock market in the Republic of Korea. Ecological Economics 58(4), 59-777.

Diamond, Douglas W. (1984): Financial intermediation and delegated monitoring. The Review of Economic Studies 51(3), 393-414. DOI: doi.org/10.2307/2297430.

Giovannini, Alessandro - Iacopetta, Maurizio - Minetti, Raoul (2013): Financial Markets, Banks, and Growth: Disentangling the links. Revue de l'OFCE, 5(131), 105-147.

Guiso, Luigi - appelli, Tullio - Padula, Mario - Pagano, M. (2005): Financial Market Integration and Economic Growth in the EU. Economic Policy 19(40), 523-577. DOI: 10.1111/j.14680327.2004.00131.x.

Gyura GÁBOR (2019): Zöldbankolás Magyarországon. Mire lenne szükség a valódi áttöréshez? https://www.bib-edu.hu/hirek/zoldbankolas_magyarorszagon_mire_lenne_szukseg_a_ valodi_attoreshez.

Hayat, Farah - Pirzadac, Muhammad D. S. - Khanb, Abid A. (2018): The validation of Granger causality through formulation and use of finance - growth - energy indexes. Renewable and Sustainable Energy Reviews 81, 1859-1867. DOI: 10.1016/j.rser.2017.05.282.

Horvath, Bálint-Mallinguh, Edmund-Fogarassy, Csaba (2018): Designing Business Solutions for Plastic Waste Management to Enhance Circular Transitions in Kenya. Sustainability 10(5), 1664. DOI: doi.org/10.339o/su10051664

Hove, Simbarashe - Tursoy, Turgut (2019): An investigation of the environmental Kuznets curve in emerging economies. Journal of Cleaner Production 236, 117-628. DOI: 10.1016/j. jclepro.2019.117628. 
IMF (2020): Financial development database. https://data.imf.org/?sk=F8032E8o-B36C-43B1$\mathrm{AC}_{2} 6-493 \mathrm{C}_{5} \mathrm{~B}_{1} \mathrm{CD}_{33} \mathrm{~B}$.

IPCC (2014): Climate Change 2014: Synthesis Report. Contribution of Working Groups I, II and III to the Fifth Assessment Report of the Intergovernmental Panel on Climate Change [Core Writing Team, Pachauri, R. K. and Meyer, L. A. (eds.)]. IPCC, Geneva, Switzerland, 151.

JIANG, CHUn - MA, XIAOXIN (2019): The Impact of Financial Development on Carbon Emissions: A Global Perspective. Sustainability 1(19), 5241-260. DOI:10.339o/su11195241.

KatircioĞlu, Salih T. - Taşpinar, Nigar (2017): Testing the moderating role of financial development in an environmental Kuznets curve: Empirical evidence from Turkey. Renewable and Sustainable Energy Reviews 68, 572-586. DOI: 10.1016/j.rser.2016.09.127.

Lanoie, Paul - Laplante, Benoit - Roy, Maite (1998): Can capital markets create incentives for pollution control? Ecological Economics 26(1), 31-41.

Levine, Ross (2001): International Financial Liberalization and Economic Growth. Review of international economics 9(4), https://doi.org/10.1111/1467-9396.00307.

Li, BAIZHAN - YAO, RUNMING (2009): Urbanisation and its impact on building energy consumption and efficiency in China. Renewable Energy 34(9), 1994-1998.

López-Menéndez, Ana J. - Pérez-Suárez, R. - Moreno, Blanca P. (2014): Re-visiting the Environmental Kuznets Curve. Journal of Environmental Management 145, 368-373.

Merton, Robert C. - Bodie, Zvi (1995): Conceptual Framework for Analyzing the Financial Environment. Chap. 1 in The Global Financial System: A Functional Perspective.

Mérő Katalın (2003): A gazdasági növekedés és a pénzügyi közvetítés mélysége. Közgazdasági Szemle L. évf. július-augusztus, 590-607.

Németh-Durkó, E. (2020): Mi áll a környezetszennyezés hátterében? A gazdasági növekedés és a szén-dioxid-kibocsátás kapcsolatának vizsgálata a környezeti Kuznets-görbével. Statisztikai Szemle (megjelenés alatt).

Naffa, Helena - Dudás, FAnni (2020): Milyen szerepet töltenek be az országszintű ESGindikátorok - valamint a globális pénzügyi inklúziós indikátorok a szociális és pénzügyi jólét meghatározásában? Köz-Gazdaság [Review of Economic Theory and Policy] 15(2), 156-162.

Niemeyer, J. (2001): Where to Go after the Lamfalussy Report? - An Economic Analysis of Securities Market Regulation and Supervision. SSE/EFI Working Paper Series in Economics and Finance.

Fain, Máté - Naffa, Helena (2019): Performance Measurement of Active Investment Strategies Using Pure Factor Portfolios. Financial and Economic Review 18(2), 52-86. DOI: https://doi. org/10.33893/FER.18.2.5286.

Ozturk, Ilhan - Acaravci, Ali (2013): The long-run and causal analysis of energy, growth, openness and financial development on carbon emissions in Turkey. Energy Economics (36), 262-267. DOI: 10.1016/j.eneco.2012.08.025.

Pablo-Romero, Maria P. - Sánchez-Braza, Antonio (2017): Residential energy environmental Kuznets curve in the EU-28. Energy (125), 44-54. DOI: 10.1016/j.energy.2017.02.091.

Paramati, Sudharshan R. - Ummalla, Mallesh - Apergis, Nicholas (2016): The effect of foreign direct investment and stockmarket growth on clean energy use across a panel of emergingmarket economies. Energy Economics (56), 29-41. DOI: 10.1016/j.eneco.2016.02.008.

PAta, Ugur K. (2018): Renewable Energy consumption, urbanization, financial development, income and $\mathrm{CO}_{2}$ emissions in Turkey: Testing EKC hypothesis with structural breaks. Journal of Cleaner Production 187, 770-779. DOI: 10.1016/j.jclepro.2018.03.236.

SAdORsky, Perry (2010): The impact of financial development on energy consumption in emerging economies. Energy Policy 38(5), 2528-2535. DOI: 10.1016/j.enpol.2009.12.048. 
Shahbaz, Muhammad - Solarin, Sakiru A. - Mahmood, Haider - Arouri, Mohamed (2013): Does financial development reduce $\mathrm{CO}_{2}$ emissions in Malaysian economy? A time series analysis. Economic Modelling 35, 145-152. DOI: 10.1016/j.econmod.2013.06.037.

Stiglitz, Joseph E. - Weiss, Andrew (1983): Incentive effects of terminations: applications to the credit and labor markets. The American Economic Review 73(5), 912-927.

Stolyarova, Elena (2013): Carbon Dioxide Emissions, economic growth and energy mix: empirical evidence from 93 countries. EcoMod 2013 Conference, Prague, Czech Republic.

Stiglitz, Joseph E. (2012): The Price of Inequality. Ww Norton \& Co., USA.

TAmazian, Artur - RaO, Bhaskara B. (2010): Do economic-financial and institutional developments matter for environmental degradation? Evidence from transitional economies. Energy Economics 32(1), 137-145.

World Bank (2012): Global Financial Development Report 2013: Rethinking the Role of the State in Finance. World Bank, Washington, DC, https://www.worldbank.org/en/publication/gfdr.

Zhang, DAYong - Zhang, Zhiwei - MANAgi, Shunsuke (2019): A bibliometric analysis on green finance: Current status, development and future directions. Finance Research Letters 29, 425430. DOI: 10.1016/j.frl.2019.02.003. 